\section{Land Application of Compost and Other Wastes (By-products) in Florida: Regulations, Characteristics, Benefits, and Concerns}

\author{
Yuncong Li ${ }^{1,6}$, Edward Hanlon ${ }^{2}$, George O’Connor ${ }^{3}$, \\ Jianjun Chen ${ }^{4}$, and Maria Silveira ${ }^{5}$
}

AdDitional INDEX wORDs. ash, water treatment residuals, food processing, phosphogypsum, soil amendment

Summary. Compost is the product resulting from the controlled biological decomposition of organic material that has been sanitized through the generation of heat and processed to further reduce pathogens as defined by the U.S. Environmental Protection Agency and stabilized to the point that the compost is beneficial to plant growth. Organic materials used for composting in Florida are mainly yard wastes (trash) and food wastes. More than $\mathbf{5 . 7}$ million tons of composts could be produced from yard trash and food waste in the state. Animal manure and biosolids (treated sludge) can also be composted, but are not discussed in this article. "Other wastes" as discussed herein [food processing wastes, coal ash, wood ash, drinking water treatment residuals (WTRs), and phosphogypsum] are by-products of leading Florida industries and are available in large quantities for reuse. About $\mathbf{5}$ million tons of food processing waste [citrus (Citrus spp.) and vegetables alone], 1.85 million tons of coal ash (from 28 coal-burning power plants), 0.05 million tons of wood ash, 1000 million tons of phosphogypsum (from the state's phosphate fertilizer industry), and significant, but unknown, amounts of WTRs are available. Due to the growing interest in sustainable agriculture practices, this article is intended to discuss the current regulations and guidelines for composting and the use of composts and other wastes in Florida, the characteristics, benefits, and concerns of Florida compost and other wastes, and current research and needs of research and extension for incorporating compost and other waste materials in Florida's sustainable agriculture. Our literature search was largely limited to studies conducted in Florida.

$\mathrm{M}$

ost Florida soils are sandy or gravelly and exhibit low $\mathrm{pH}$, low organic matter content, and poor water and nutrient holding capacities (Brown et al., 1990). Studies conducted in Florida show that composts made from a number of organic waste products, as well as selected solid wastes (or byproducts) themselves, can be used as

${ }^{1}$ Professor, Tropical Research and Education Center and Soil and Department of Soil and Water Science, University of Florida, 18905 Southwest 280 Street, Homestead, FL 3303

${ }^{2}$ Professor, Southwest Florida Research and Education Center and Department of Soil and Water Science, University of Florida, 2686 Highway 29 North, Immokalee, FL 34142

${ }^{3}$ Professor, Department of Soil and Water Science, University of Florida, 106 Newell Hall, P.O. Box 110510, Gainesville, FL 32611

${ }^{4}$ Associate Professor, Mid-Florida Research and Education Center and Department of Environmental Horticulture, University of Florida, 2725 Binion Road, Apopka, FL 32703

${ }^{5}$ Assistant Professor, Range Cattle Research and Education Center and Department of Soil and Water Science, University of Florida, 3401 Experiment Station, Ona, FL 33865

${ }^{6}$ Corresponding author. E-mail: yunli@ufl.edu. soil amendments to increase soil organic matter, supply nutrients, modify soil $\mathrm{pH}$, remediate arsenic (As) and phosphorus $(\mathrm{P})$ contamination, and improve soil physical properties. However, few of the untreated byproducts are used commercially as soil amendments except composts (Moss et al., 2002). Even compost is not widely used in Florida. Currently, Florida produces about 0.15 million tons of composts per year, which represent only $2.7 \%$ of available organic materials for composting, and less than $0.01 \%$ of potential needs for agricultural and landscape purposes (Li et al., 2000). Factors affecting utilization of by-products are cost,

\begin{tabular}{llll}
\hline $\begin{array}{l}\text { Units } \\
\begin{array}{l}\text { To convert U.S. to SI, } \\
\text { multiply by }\end{array}\end{array}$ & U.S. unit & SI unit & $\begin{array}{l}\text { To convert SI to U.S., } \\
\text { multiply by }\end{array}$ \\
\hline 2.54 & inch(es $)$ & $\mathrm{cm}$ & 0.3937 \\
0.4536 & $\mathrm{lb}$ & $\mathrm{kg}$ & 2.2046 \\
0.5933 & $\mathrm{lb} / \mathrm{yard}^{3}$ & $\mathrm{~kg} \cdot \mathrm{m}^{-3}$ & 1.6856 \\
1 & $\mathrm{ppm}$ & $\mathrm{mg} \cdot \mathrm{kg}^{-1}$ & 1 \\
0.9072 & ton $(\mathrm{s})$ & $\mathrm{Mg}$ & 1.1023 \\
2.2417 & ton/acre & $\mathrm{Mg} \cdot \mathrm{ha}^{-1}$ & 0.4461
\end{tabular}
underway. availability, quality, environmental concerns, and regulations. Landfill or other disposal alternatives for wastes are often more convenient and cheaper. Availability in the local area and quality of final waste products (by-products) are important issues for users. State regulations often do not favor reuse or make reuse difficult for the average grower/farmer. More research and extension efforts are needed to develop better and more consistent products, to investigate sustainable management practices for application, and to educate regulators and users on how compost and other wastes can be safely reused.

\section{Regulations and guidelines for composting and use of composts and other wastes in Florida}

Management of compost and wastes, except water treatment residuals (WTRs), are regulated by Florida Department of Environmental Protection (FDEP) based on Florida Statutes with specific Florida Administrative Codes (FAC) (Table 1). WTRs are currently regulated based only on the FDEP guideline.

The University of Florida has devised the Florida P index to address the need for environmental determinations for $\mathrm{P}$ additions from manures (Nair and Graetz, 2002). The use of this $\mathrm{P}$ Index leads to characterizing the potential for $\mathrm{P}$ movement to groundwater or to adjacent bodies of water (Hurt et al., 2006). Currently, work linking the P Index with composts and other by-products is

Composting/composts. Florida composting is regulated by FAC 62-701 (Solid waste management facilities) and FAC 62-709 (Criteria for the production and use of compost made from solid waste) (Table 1 ). FAC 62-701 contains general provisions for solid waste management facilities, whereas FAC 62-709 is 
specific to composting and compost use. FDEP is currently considering revisions that will make the state rule even more restrictive for land application of organic wastes in Florida (Kessler Consulting, 2006).

Composting facilities in Florida fall into three regulatory categories: exempt, registration (yard trash processing), and full permit facilities. Backyard, on-farm, and microscale composting facilities are exempt from state regulation because these composting operations are not expected to have adverse impacts on public health and the environment. Facilities composting only yard waste are eligible for registration and are subject to fewer restrictions regarding processing and distribution of compost. All other types of organic recycling facilities, like those composting food residuals, are subject to greater restriction than similar-sized facilities that compost only yard trash (FDEP, 2000; Jamieson et al., 2003; Kessler Consulting, 2006; Olexa et al., 2003).

Based on physical and nutrient characteristics (e.g., feedstock, product maturity, foreign matter content, particle size, and trace elements concentrations) of the compost, Florida divides compost into seven grades: yard trash $(\mathrm{Y})$, yard manure $(\mathrm{YM})$, and types $\mathrm{A}, \mathrm{B}, \mathrm{C}, \mathrm{D}$, and $\mathrm{E}$ composts (FDEP, 2000) (Table 2). Yard trash and manure composts contain low concentrations of trace elements and have unrestricted use. Use of type D compost has greater restrictions on public contact, and type $\mathrm{E}$ compost must be disposed of pursuant to FAC 62-701, unless demonstrated that use of this material will not endanger the public or the environment. The trace metal concentrations of compost are governed on four levels

Table 1. Management rules of compost and other wastes based the Florida Administrative Code (FAC) or guidance [Florida Department Environmental Protection (FDEP), 2009].

\begin{tabular}{|c|c|c|}
\hline Waste & $\mathrm{FAC}^{\mathrm{z}}$ & Title \\
\hline \multirow[t]{2}{*}{ Compost } & $62-701$ & Solid waste management facilities \\
\hline & $62-709$ & $\begin{array}{l}\text { Criteria for the production and } \\
\text { use of compost made from solid waste }\end{array}$ \\
\hline Food processing & $62-701$ & Solid waste management facilities \\
\hline Coal ash & $62-701$ & Solid waste management facilities \\
\hline \multirow[t]{2}{*}{ Wood ash } & $62-701$ & Solid waste management facilities \\
\hline & $62-702$ & Solid waste combustor ash management \\
\hline $\begin{array}{l}\text { Drinking water } \\
\text { treatment residuals }\end{array}$ & $\mathrm{N} / \mathrm{A}$ & $\begin{array}{c}\text { Guidance for land application of drinking } \\
\text { water treatment sludge (FDEP, 2006) }\end{array}$ \\
\hline Phosphogypsum & $62-673$ & Phosphogypsum management \\
\hline
\end{tabular}

${ }^{2} \mathrm{~N} / \mathrm{A}=$ not applicable ("codes," Table 3), and are tied to compost class and subsequent uses (Table 2). There are no specific pathogen requirements, although fecal coliform testing is required for reporting purposes (FDEP, 2000).

Coal ash. Coal ash (fly ash and bottom ash) is solid waste regulated at the federal level using the Resource Conservation and Recovery Act (RCRA) of 1976, and Subtitle C or D may apply. Subtitle D is for nonhazardous wastes that are subject to individual state laws. Most states, including Florida, have exempted coal ash from hazardous waste regulation. Coal ash management is covered by FAC 62-701, which has no specific requirements for land application. Nevertheless, FDEP requires the permit for using coal ash by following FAC 62-701, 62-709, and 62-4.070 and makes it almost impossible for agricultural use of coal ash.

WoOD ASH. Wood products burned in air curtain incinerator facilities in Florida include landscape debris, yard waste, private operation waste, and emergency reduction waste from natural disasters. The production and use of wood ash are not specified with a FAC, but can be regulated under FAC 62-701 (Solid waste management facilities) or FAC 62-702 (Solid waste combustor ash management). FDEP memo (SWM05.6) states that "clean" dry wood may be burned in air curtain incinerators or combustors, and (in some cases) through simple open burning (FDEP, 2002). Clean wood includes only wood that is free of paint, glue, filler, pentachlorophenol, creosote,

Table 2. Compost classification based on the type of feedstock, product maturity, foreign matter content, particle size, and heavy (trace) metal concentrations [Florida Administrative Code 62-709.550.600 (Florida Department Environmental Protection, 2009)].

\begin{tabular}{|c|c|c|}
\hline Compost Type & Characteristics & Use restriction \\
\hline $\mathrm{Y}$ & $\begin{array}{l}\text { Made from yard trash, mature /semimature, any texture, }<2 \% \text { foreign } \\
\text { matter, code } 1 \text { heavy metals }\end{array}$ & Unrestricted use \\
\hline A & $\begin{array}{l}\text { Made from solid waste, mature, fine texture, }<2 \% \text { foreign matter, code } 1 \\
\text { heavy metals }\end{array}$ & Unrestricted use \\
\hline $\mathrm{C}$ & $\begin{array}{l}\text { Made from solid wastes, mature/semimature, any texture, }<10 \% \text { foreign matter, } \\
\text { code } 1,2 \text {, or } 3 \text { (low, medium, or high) heavy metals }\end{array}$ & $\begin{array}{l}\text { For agricultural; public } \\
\text { contact allowed }\end{array}$ \\
\hline $\mathrm{D}$ & $\begin{array}{l}\text { Made from solid wastes, not mature, any texture, }>10 \% \text { foreign matter, code } \\
1,2 \text {, or } 3 \text { (low, medium, or high) heavy metals }\end{array}$ & $\begin{array}{l}\text { For land fill, land reclamation; } \\
\text { public contact not allowed }\end{array}$ \\
\hline $\mathrm{E}$ & Made from solid wastes, metals exceed standards (code 4 metals) & Must be disposed \\
\hline
\end{tabular}


tar, asphalt, or other wood preservatives or treatments. Wood ash from the burning of yard trash may be used as a soil amendment or incorporated into mulch or compost products in the same conditions as yard trash.

WTRs. There is no FAC for land use of WTRs; however, FDEP published the "Guidance for land application of drinking water plant sludge" in 2006. Based on a characterization study of WTRs (Townsend et al., 2001), FDEP determined that "beneficial land application of lime-stabilized sludge from drinking water systems is not expected to create any significant threat to public health or the environment. For this reason, no additional regulation or approval by FDEP is required prior to land application of WTRs. FDEP recommends that WTRs be applied at a rate no greater than 9 tons/acre per year to minimize movement of metals into the environment. In addition, land application of WTRs must meet three general criteria: 1) not be a hazardous waste, 2) not cause violation of groundwater and surface water standards and criteria, and 3) not cause fugitive dust emissions or objectionable odors or create a public nuisance." However, FDEP does not approve land application of alum or ferric WTRs, unless the person seeking to apply the residue can provide reasonable assurance (no criteria given) that no threat to public health or the environment will exist based upon site-specific or material-specific criteria (FDEP, 2006).

Phosphogypsum. Phosphogypsum must be stockpiled in stacks after a 1989 U.S. Environmental Protection Agency (USEPA) rule banning its use based upon the trace amount of radioactivity in the phosphogypsum. Land application of most of the phosphogypsum produced in Florida would only be possible if the USEPA raises the limit on radioactivity $(370$ $\left.\mathrm{Bq} \cdot \mathrm{kg}^{-1}\right)$. FAC $62-673$ specifically addresses phosphogypsum management. The regulation (62-673.300) clearly states that 1 ) no person shall dispose of, or store before disposal, any phosphogypsum except within a phosphogypsum stack system permitted by FDEP; and 2) the material is subject to the licensure requirements of Chapter 404, Florida Statutes.

\section{Characteristics of Florida compost and other wastes}

Compost. Compost is an organic matter source that can improve the chemical, physical, and biological characteristics of soils or growing media (Table 4). Composts are made wastes and other organic wastes from municipal solid wastes (MSW). According to the latest FDEP report (FDEP, 2009), Florida collected about 35 million tons of MSW, which include about 4 million tons of yard trash (yard waste), and about $34 \%$ of the yard trash (not MSW in general) was recycled in 2006. More than 1.7 million tons of food wastes were collected, but only $\approx 1 \%$ was reused. More than 5 million tons of composts could be generated from yard trash and food waste (Table 5). However, less than 0.15 million tons of compost are produced annually in Florida (Ozores-Hampton and Obreza, from organic feedstocks, mainly yard

2007). Currently, there are 83 private and public facilities registered with FDEP to produce composts, and the "Solid waste solid waste facility inventory report" identifies only 29 active facilities in 2007 (FDEP, 2007b). Because Florida's regulatory definition of "compost" includes mulch, screenings, and other products, most of the active composting facilities do not actually produce compost, but only mulches and other nondecomposed products. The Florida Organic Recycling Center for Excellence (Kessler Consulting, 2006) reported that as of Sept. 2005, FDEP permitted only five composing facilities (Sumter County, Black Gold, Reedy Creek, Busch Gardens, and Jacksonville Zoological Gardens). Regulations, waste composition, and cost play critical roles in explaining the lack of compost facilities. The regulations strongly favor processing rather than composting because a full permit is required for compost facilities, with

Table 3. Trace metal limits in composts based on Florida Administrative Code 62-709.550 (Florida Department Environmental Protection, 2009).

\begin{tabular}{llccc}
\hline & \multicolumn{4}{c}{ Metal concn $\left(\mathbf{m g} \cdot \mathbf{k g}^{-\mathbf{1}} \text { dry wt }\right)^{\mathrm{z}}$} \\
\cline { 2 - 5 } Heavy metal & \multicolumn{1}{l}{} & $\mathbf{2}$ & $\mathbf{3}$ & $\mathbf{4}$ \\
\hline Cadmium & $<15$ & 15 to $<30$ & $30-100$ & $>100$ \\
Copper & $<450$ & 450 to $<900$ & $900-3,000$ & $>3,000$ \\
Lead & $<500$ & 500 to $<1,000$ & $1,000-1,500$ & $>1,500$ \\
Nickel & $<50$ & 50 to $<100$ & $100-500$ & $>500$ \\
Zinc & $<900$ & 900 to $<1,800$ & $1,800-10,000$ & $>10,000$ \\
\hline
\end{tabular}

${ }^{\mathrm{z}} 1 \mathrm{mg} \cdot \mathrm{kg}^{-1}=1 \mathrm{ppm}$.

Table 4. Typical characteristics of composts and other wastes.

\begin{tabular}{|c|c|}
\hline Waste & Characteristics \\
\hline Compost & $\begin{array}{l}\text { Organic matter, macro- and micronutrients, suitable for } \\
\text { land application }\end{array}$ \\
\hline Food processing & $\begin{array}{l}\text { Organic matter, macro- and micronutrients, suitable for } \\
\text { land application }\end{array}$ \\
\hline \multirow[t]{2}{*}{ Coal ash } & $\begin{array}{l}\text { Fly ash: fine, powdery particles, primarily oxides, sulfates, } \\
\text { phosphates, partially converted dehydrated silicates, and } \\
\text { other inorganic particulate matter residual from } \\
\text { coal combustion }\end{array}$ \\
\hline & $\begin{array}{l}\text { Bottom ash: heavy, coarse, granular, primarily silica, } \\
\text { alumina, and iron, as well as low amounts of calcium, } \\
\text { magnesium sulfates, and other inorganic materials }\end{array}$ \\
\hline Wood ash & $\begin{array}{l}\text { Organic and inorganic residue, fine texture, } \\
\text { high } \mathrm{pH}(9-13) \text {, good source of calcium, } \\
\text { magnesium, potassium, phosphorus, and } \\
\text { micronutrients }\end{array}$ \\
\hline $\begin{array}{l}\text { Drinking water } \\
\text { treatment residuals }\end{array}$ & $\begin{array}{l}\text { Fine texture, high organic carbon, calcium, iron or } \\
\text { aluminum, activated carbon, and polymers, } \\
\text { wide range of } \mathrm{pH}\end{array}$ \\
\hline Phosphogypsum & Mainly gypsum, high calcium, and sulfur \\
\hline
\end{tabular}


Table 5. Estimated total masses, current usage, and potential market for composts and other wastes in Florida (FDEP, 2007a).

\begin{tabular}{lccc}
\hline Waste & $\begin{array}{c}\text { Total/potential } \\
\text { wt }(\mathbf{1 0 0 0} \text { tons })^{\mathbf{z}}\end{array}$ & $\begin{array}{c}\text { Used for } \\
\text { land application } \\
(\mathbf{1 0 0 0} \text { tons })\end{array}$ & $\begin{array}{c}\text { Potential for } \\
\text { land use } \\
(\mathbf{1 0 0 0} \text { tons })\end{array}$ \\
\hline Compost & 5,700 & 150 & 62,000 \\
Food processing & $>5,000$ & Very low & Very low \\
Coal ash & 1,850 & Very low & Very low \\
Wood ash & $20-50$ & $<5$ & Very high \\
Drinking water & Unknown & Very low & Very low \\
treatment residuals & & & Very low \\
Phosphogypsum & $1,000,000$ & Very low & .
\end{tabular}

${ }^{\mathrm{z}} 1000$ tons $=907.1847 \mathrm{Mg}$.

some exceptions. Most yard waste is woody materials and more suitable as a bulking agent than as compost feedstock. The costs of producing compost are often greater than landfill tipping fees or the sale of mature compost. Florida has a large potential compost market, but the demand for compost is not well developed. Slivka et al. (1992) estimated that the Florida agricultural industry alone could potentially use more than 20 million tons of compost per year, while landscape could use as much as 42 million tons of compost per year. Shiralipour (1998) pointed out that critical factors affecting marketing of compost were availability, cost, and quality.

Food PRocessing WASTES. Food processing wastes can come from plant and animal materials. The Florida food processing industry is dominated by the production of processed citrus, vegetables, and sugar, generating more than 5 million tons of wastes per year (Barker et al., 2000). The wastes are mainly used for animal feed and high-value uses such as essential oils, and chemical and pharmaceutical materials (flavonoid and dlimonene) (Goodrich and Braddock, 2006; Westendorf and Myer, 2004). There are few reports of directly using food wastes as soil amendments. The Florida sugarcane (Saccharum spp.) industry processes more than 13 million tons of sugarcane per year and produces large amounts of solid waste, including bagasse. Bagasse is not widely used in agriculture, but has been suggested as a valuable soil amendment in Florida (Stoffella et al., 1996). Currently, ash resulting from burning bagasse is allowed to be used as a soil amendment (FDEP memo no. SWM-05.6).
CoAl ash. The American Coal Ash Association (Aurora, CO) estimated that $>120$ million tons of coal combustion products, including $\approx 88$ million tons of fly and bottom ash, was produced in 2003 . Less than $38 \%$ of coal ash produced was used, and agricultural use was only 20,000 tons per year, or about $0.02 \%$ of coal ash produced (American Coal Ash Association, 2001). Miller et al. (2000) estimated that Florida produced $\approx 1.85$ million tons of ash from 28 coal-burning power plants, and used $\approx 1300$ tons on crop land and forests in 1994. Despite the potential for more widespread use, agricultural use of coal ash has been limited by high transportation and application costs as well as by concerns that the product increases trace element concentrations in crops and surrounding ecosystems (Gainer, 1996).

Wood AsH. Wood ash is the residue remaining after the combustion of wood. Historically, wood ash was mainly used to produce potash for fertilizer and to produce alkali for industry. However, as other potash production technologies became more economical, the value of wood ash as a raw material has decreased. Currently, $\approx 3$ million tons of wood ash is produced annually in the United States (Risse and Harris, 2007). While $80 \%$ of all wood ash is land applied in the northeastern United States, less than $10 \%$ is land applied in the southeastern United States. The estimated annual production of wood ash in Florida is about 20 to 50 thousand tons. In a survey of more than eighty southeastern U.S. paper mills, $60 \%$ of the responding mills reported an interest in land application (Risse and Harris, 2007). Wood ash composition can be highly variable depending on geographical location and industrial processes. Arsenic and chromium $(\mathrm{Cr})$ are the two primary elements that require special attention for wood ash management (Shieh, 1998). Long-term uses of the wood ash can build up trace elements in soils, which can limit the beneficial use of wood ash in agriculture.

WTRs. WTRs are waste products of water purification that, by virtue of their composition and reactivity, have potential for environmental remediation as a soil amendment (Hughes et al., 2005; Livesey and Huang, 1981; Makris and O'Connor, 2007). WTRs are primarily sediment, metal [aluminum $(\mathrm{Al})$, iron $(\mathrm{Fe})$, or calcium (Ca)] oxide/hydroxide, activated carbon $(\mathrm{C})$, and polymers removed from the raw water processed during the water purification process (Elliott and Dempsey, 1991; Maurer and Boller, 1999). Using the metal salts causes the WTRs surfaces to be enriched in $\mathrm{Al}$ - and $\mathrm{Fe}$-oxide and hydroxide functional groups. This enrichment increases the WTRs affinity and capacity to sorb P (American Society of Civil Engineers, 1996; Dayton et al., 2003; Makris et al., 2004a, 2004b; O'Connor et al., 2002; Sarkar et al., 2006). Various sources of WTRs have different physicochemical properties and sorption characteristics. Some water treatment facilities employ advanced treatment processes to meet strict drinking water standards for As or radionuclides. The WTRs formed as a result of such processes can contain problematic metals [e.g., As and selenium (Se)], radionuclides [e.g., radium $(\mathrm{Ra})]$, nitrates, and salts. More than 2 million tons of WTRs are generated from drinking water facilities in the United States daily (Prakash and Sengupta, 2003). The total amount generated in Florida is unknown, but the mass is expected to be significant, and to increase as the population increases. WTRs can be disposed directly to a receiving stream; to sanitary sewers; to a landfill, assuming that the residual contains no free-draining water and does not have toxic characteristics as defined by the toxicity characteristic leaching procedure (TCLP) test; and by land application (Chwirka et al., 2001). Land application is an attractive and less expensive alternative means of WTRs disposal and may have the added benefit of immobilizing $\mathrm{P}$ 
and other oxyanions in poorly sorbing soils. The high amorphous $\mathrm{Al}$ or Fe content of the WTRs can increase the $\mathrm{P}$ sorption capacity of poorly $\mathrm{P}$ sorbing soils (Elliott et al., 1990, 2002; O’Connor et al., 2002).

Phosphogypsum. In excess of 40 million tons of phosphogypsum, a waste product of phosphate mining, are produced per year and add to an estimated 1000 million tons stored in 25 stacks in Florida (Florida Institute of Phosphorus Research, 2007). This storage constitutes a potential longterm ecological problem in Florida. The USEPA requires stacking of phosphogypsum because radiation levels exceed the established limit set by USEPA. The USEPA limit is much lower than the limit in other phosphogypsum-producing countries. The solubility of Ra sulfate is much lower than calcium sulfate, meaning that with time, the calcium sulfate dissolves in Florida's climate, effectively concentrating the $\mathrm{Ra}$ sulfate, and increasing the radiation problem within the stacks.

Phosphogypsum can alleviate Al toxicity in subsoils, act as a source of plant available $\mathrm{Ca}$, sulfur $(\mathrm{S})$, and $\mathrm{P}$, and promote soil aggregation and C sequestration. The use of phosphogypsum in agriculture is hampered by low-level radioactivity. In 1992, the USEPA ruled that phosphogypsum intended for most applications, including agricultural and construction use, must have a certified average $\mathrm{Ra}\left({ }^{226} \mathrm{Ra}\right)$ concentration $\leq 370 \mathrm{~Bq} \cdot \mathrm{kg}^{-1}$. Central Florida phosphogypsum ranges from 740 tol $295 \mathrm{~Bq} \cdot \mathrm{kg}^{-1}$. Phosphogypsum formed during the chemical processing of northern Florida rock has only 185 to $370 \mathrm{~Bq} \cdot \mathrm{kg}^{-1}$ and has potential for land application.

\section{Benefits of composts for land application reported in Florida}

INCREASED NUTRIENT SUPPLY. Composts can be valuable sources of nutrients, particularly $\mathrm{N}$ and micronutrients. However, nutrient concentrations and availabilities in composts vary considerably depending on the mineralization rates of composts, and the initial concentrations available in the feedstocks used to create the compost. Mineralization of compost depends on compost composition, maturity, and the soil conditions (moisture, temperature, etc.). About
$25 \%$ of organic nitrogen $(\mathrm{N})$ is $\mathrm{min}$ eralized from MSW composts at year one (He et al., 2000; Stoffella et al., 1997). Numerous studies have been conducted to evaluate nutrient availability from compost amendments applied in crop systems in Florida. Compost can be a partial substitute for inorganic fertilizer for tomato [Solanum lycopersicum (Stoffella and Graetz, 2000)] and pepper [Capsicum annumm (Roe et al., 1997)]. Csizinszky and Stanley (1998) reported that concentrations of inorganic N, P, potassium (K), Ca, magnesium $(\mathrm{Mg}), \mathrm{Al}, \mathrm{Fe}$, manganese $(\mathrm{Mn})$, and zinc $(\mathrm{Zn})$ in soils increased linearly with increasing compost rates from 0 to 15 tons/acre. Similar findings were also reported by Clark et al. (1995), Litvany and OzoresHampton (2002), and Roe et al. (1997).

INCREASED SOIL ORGANIC C CONTENT. Composts usually contain $>1 \%$ organic $\mathrm{C}$, and soil incorporation can increase soil organic $\mathrm{C}$ contents. Zinati et al. (2001) conducted a field investigation on accumulation of total organic $\mathrm{C}$ and the increases in amounts of soil organic $\mathrm{C}$ in the humin, humic acid, and fulvic acid fractions in a gravelly calcareous soil amended with three composts or inorganic fertilizer (1.25 ton/acre). Clean organic waste compost (COW) (100\% yard waste plus food waste), cocompost $(75 \%$ yard waste and $25 \%$ biosolids), and biosolids compost (100\% biosolids) applied at 32 , 37 , and 7 tons/acre, respectively, were incorporated into soil beds. Total organic $\mathrm{C}$ contents in the amended soils were 4-, 3-, and 2-fold higher in COW compost, cocompost, and biosolids compost treatments, respectively, than those in fertilizer-treated or nontreated soils at the end of the 3-year experiment. The use of COW compost to amend soils significantly increased the amount of organic $\mathrm{C}$ in the humin, humic acid, and fulvic fractions, whereas similar changes were absent in soils treated with inorganic fertilizer or nontreated soils.

\section{Suppressed soilborne diseases and nematodes}

Composts can suppress soilborne nematodes and plant pathogens, and may represent alternatives to fumigation with methyl bromide in vegetable crop production systems (Stoffella and Li, 2001), but results have been inconsistent (Table 6). MSW compost significantly reduced root knot nematode (Meloidogyne spp.), but increased the incidences of tomato early blight (Alternaria solani) and other diseases (Bryan et al., 1997). The MSW compost reduced the incidence of rhizoctonia root rot (Rhizoctonia solani) in southernpea (Vigna unguiculata) compared with the untreated control (Ozores-Hampton and McMillan, 1994). However, using similar composts, Mannion et al. (1994) found no effects on plantparasitic nematode populations during a 2-year experiment. Ritzinger et al. (1997) found inconsistent effects of composts on the root knot nematode populations in okra (Abelmoschus esculentus) plots, yet the effects of compost on okra growth were consistently beneficial.

INCREASED CROP YIELDS. In Florida, crop yield responses to compost amendments have been evaluated for black-eyed pea ( $V$. unguiculata ssp. unguiculata), broccoli (Brassica oleracea var. italica), corn (Zea mays), cucumber (Cucumis satipus), eggplant (Solanum melongena), okra, pepper, snap bean (Phaseolus vulgaris), squash (Cucurbita spp.), tomato, and watermelon (Citrullus lanatu) (Ozores-Hampton et al., 1998). In most experiments, composts had positive effects on vegetable production, but in a few cases, compost amendments reduced crop yields (Table 7). Responses of vegetable growth are significantly affected by compost composition, maturity, and soil conditions. Because of poor compost quality, tomato grown in MSW compostamended calcareous soil had lower marketable yields in the first year than tomato grown in unamended soil. However, in the second year, tomato yields were significantly greater in the compost-amended soils (Bryan et al., 1997). Obreza and Reeder (1994) also suggested that the lower yields of tomato from compost-amended plots were caused by incorporating immature compost. Responses of crop to compost amendments largely depend on compost quality. Reliable methods to assess compost maturity, stability, and pathogen suppressivity are needed to characterize compost quality. 
Table 6. Effects of compost amendment on the incidence of root knot nematode (RKN (Meloidogyne spp.)], stem canker (Clavibacter michiganensis), root rot (Rhizoctonia solani), and bacterial wilt (Erwinia tracheiphila) of vegetables grown in Florida (Li et al., 2000).

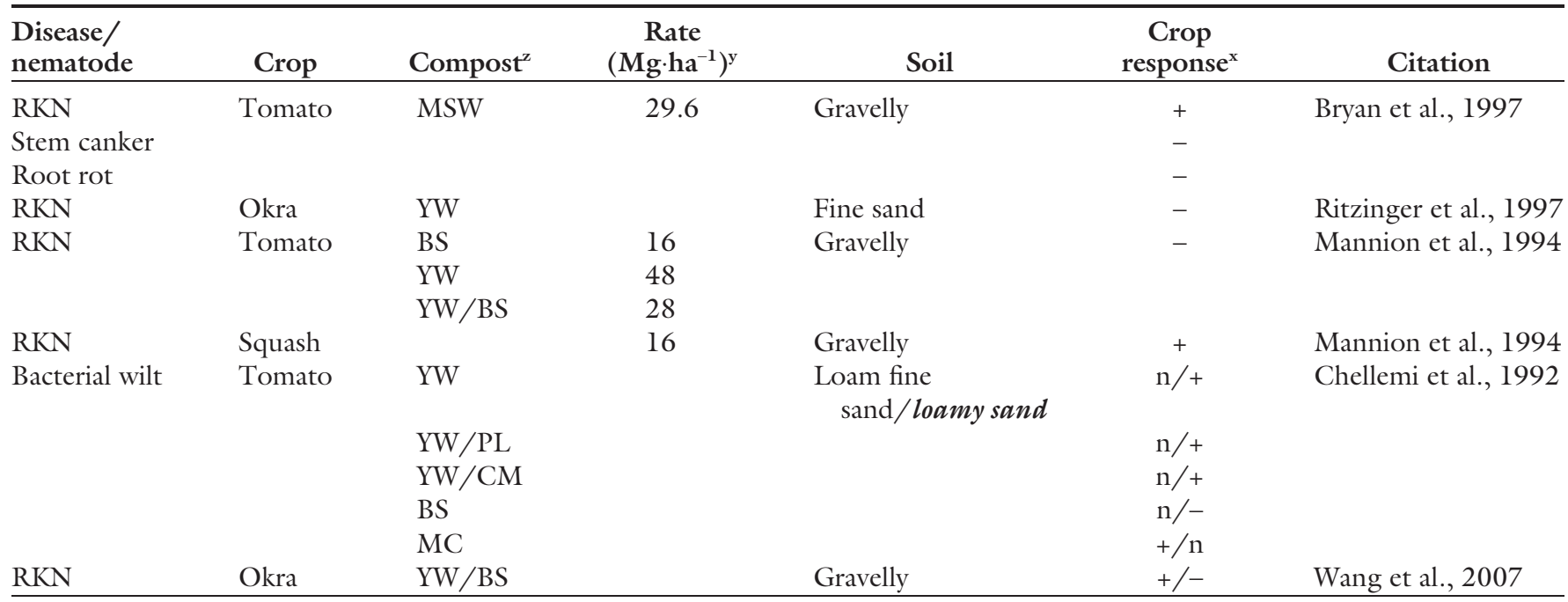

${ }^{\mathrm{z}} \mathrm{MSW}=$ municipal solid waste, $\mathrm{YW}=$ yard waste, $\mathrm{BS}=$ biosolids, $\mathrm{PL}=$ poultry litter, $\mathrm{CM}=$ cow manure, $\mathrm{MC}=$ mushroom compost

${ }^{\mathrm{y}} \mathrm{l} \mathrm{Mg} \cdot \mathrm{ha}^{-1}=0.446 \mathrm{l}$ ton/acre.

${ }^{x}$ Responses of $\mathrm{n} /+$ and $\mathrm{n} /-$ mean no response or positive response and no response or negative response, respectively.

Table 7. Yield responses of tomato to compost amendments from experiments conducted in Florida ( $\mathrm{Li}$ et al., 2000).

\begin{tabular}{|c|c|c|c|c|}
\hline Compost $^{\mathrm{z}}$ & $\begin{array}{c}\text { Rate } \\
\left({\left.\mathrm{Mg} \cdot \mathrm{ha}^{-1}\right)^{\mathrm{y}}}\right.\end{array}$ & Soil & $\begin{array}{c}\text { Crop } \\
\text { response }^{\mathrm{x}}\end{array}$ & Reference \\
\hline $\mathrm{MSW} / \mathrm{BS}$ & 30 & Gravelly & - & Bryan et al., 1997 \\
\hline $\mathrm{MSW} / \mathrm{BS}$ & 30 & Gravelly & + & Bryan et al., 1997 \\
\hline $\mathrm{MSW} / \mathrm{BS}$ & 75,112 & Fine sand & - & Obreza and Reeder, 1994 \\
\hline MSW & 30 & Gravelly & + & Bryan et al., 1997 \\
\hline MSW & 13,27 & Fine sand & + & Obreza and Reeder, 1994 \\
\hline MSW & 60,120 & Gravelly & + & Bryan et al., 1995 \\
\hline YW & $12,24,36$ & Fine sand & + & Csizinszky and Stanley, 1998 \\
\hline PR & 188 & Fine sand & + & Stoffella and Graetz, 2000 \\
\hline
\end{tabular}

\section{Benefits of other wastes for land application in Florida}

FOOD PROCESSING WASTE. Sugarcane filter cake is a waste byproduct of the sugarcane industry. The filter cake residue is mixed with water and piped from the processing mill into fields and allowed to remain in bogs for more than 1 year. The end product is compost with a soil-like appearance that is particularly high in Ca. Sugarcane filter cake compost has been used as a partial substitute for peat in containerized seedling production systems of citrus and tomato (Stoffella et al., 1996; Stoffella and Graetz, 2000). There is no known research on land application of food processing wastes for citrus and vegetables.

COAL ASH. Numerous benefits can result from the application of coal ash to agricultural soils, including improvement of soil texture, modification of soil $\mathrm{pH}$, and provision of essential plant nutrients for crop production. Townsend and Hodgson (1973) reported that the particle fractions of coal ash samples ranged from $45 \%$ to $70 \%$ silt and $1 \%$ to $4 \%$ clay. The fine-sized ash particles are expected to increase total porosity of soils. Coal ash contains $>40$ elements, including most of the micronutrients needed for adequate plant growth. Application of coal ash increases nutrient bioavailability in amended soils. A mixture of fly ash and biosolids applied to a gravelly soil in southern Florida increased tomato yields by $14 \%$ to $71 \%$ (Li et al., 2002). Soil concentrations of extractable $\mathrm{Fe}$, nickel $(\mathrm{Ni})$, and molybdenum (Mo) were also increased; however, only concentrations of $\mathrm{Mn}$ and Mo were increased in the plants. Research conducted by the Electric Power Research Institute (EPRI) indicated that mixtures of fly ash, bottom ash, and biosolids can be ideal growth media for horticultural ornamentals and turfgrass sod. The mixtures have low density, a wide particle size distribution, resistance to decomposition, and high availability in urban areas. Chen and Li (2006a, 2006b) indicated that utilization of fly ashes as container substrate amendments may represent a new market for the beneficial use of coal combustion byproducts.

Wood AsH. The only refereed publication found related to beneficial land use of wood ash in Florida is Chirenje and Ma (2002). The study was conducted on acidic sandy soil (pH 5.6) in Hawthorne, FL, during 1995-97. The boiler wood ash was applied at rates of 900 and 1800 million tons on the soil surface or incorporated to a depth of 16 inches. Application of wood ash increased soil $\mathrm{pH}(>9)$, plant available water $(\approx 12 \%)$, and reduced soil bulk density. Plant-available macronutrients $(\mathrm{Ca}, \mathrm{Mg}, \mathrm{K}$, and $\mathrm{P})$ and micronutrients [Fe, $\mathrm{Mn}$, copper $(\mathrm{Cu})$, and $\mathrm{Zn}$ ] increased substantially after ash application.

WTRs. Many Florida soils are characterized by low $\mathrm{P}$ sorbing 
capacities, and are often accompanied by high water tables. The combination of characteristics makes these soils vulnerable to $\mathrm{P}$ losses and negative water quality impacts (He et al., 1999; Novak and Watts, 2004). Land application of WTRs can be a costeffective treatment for effectively sorbing excess levels of labile $\mathrm{P}$ in soils. The high amorphous $\mathrm{Al}$ or $\mathrm{Fe}$ content of the WTRs can increase soil P sorption capacity (Elliott et al., 1990, 2002; O'Connor et al., 2002). Several studies have shown that landapplication of WTRs significantly reduced runoff- $P$ from agricultural fields (Dayton et al., 2003; Gallimore et al., 1999; Haustein et al., 2000). Other studies showed that WTRs reduced $\mathrm{P}$ leaching in Florida Spodosols (Elliott et al., 2002; O'Connor et al., 2005; Silveira et al., 2006), and eventually prevented $\mathrm{P}$ losses to contaminated groundwater (Oladeji et al., 2009). Agyin-Birikorang et al. (2007) reported that WTR-immobilized $\mathrm{P}$ will remain fixed for a long time (>7.5 years), and that within the commonly encountered $\mathrm{pH}$ range of agricultural soil, WTR-immobilized $\mathrm{P}$ is stable (Agyin-Birikorang and O'Connor, 2007).

Phosphogypsum. According to Alcolordo et al. (1998), three main avenues of use for phosphogypsum have been explored: 1 ) recovery of the $S$ value is technically feasible, but not currently economical; 2) use as a base and as fill in road construction is feasible and economical, but is not permitted by the USEPA now because of the material's radionuclide content; and 3) use as a soil amendment. Phosphogypsum is an excellent source of $\mathrm{Ca}$ and especially $\mathrm{S}$ on agricultural land. Based on a field study, Rechcigl and Mislevy (1997) observed that application of phosphogypsum resulted in increased stargrass (Cynodon spp.) yields. No refereed publication related to beneficial use of phosphogypsum in Florida can be found after 2000 .

\section{Concerns surrounding reuse of compost and other wastes in Florida}

Composts. Composts are produced from organic wastes and, consequently, environmental concerns are always an issue in compost utilization. Of particular concern is the possibility that compost may contribute to trace element accumulation in treated soils (Zinati et al., 2004), and contamination of the edible parts of crop plants (Ozores-Hampton et al., 1997). Excess nutrients or metals released from composts can also be leached from the root zone by irrigation or rainfall ( $\mathrm{Li}$ et al., 1997). Ozores-Hampton et al. (1997) measured trace elements in tomato and squash fruit from a compostamended field, and found no significant changes in concentrations of cadmium $(\mathrm{Cd}), \mathrm{Cu}$, lead $(\mathrm{Pb}), \mathrm{Ni}$, and $\mathrm{Zn}$ due to compost treatments. Accordingly, the authors suggested that use of compost at reasonable field-application rates was suitable for producing vegetables for human consumption. Precautions, safety hazards, and regulations pertaining to composts have been reviewed by Epstein (1997), Ozores-Hampton et al. (1998), and Moss et al. (2002). High variability in the quality of operations between and within compost production facilities contributes to unpredictable compost quality. Often, immature composts result in plant phytotoxicity (Li et al., 2000). The introduction of human pathogens, viable weed seeds, and high salt concentrations to compostamended soils is possible. Moss et al. (2002) indicated that the primary concerns with respect to MSW and yard waste composts include organic contaminants and herbicides. However, these concerns were not studied or reported by scientists in Florida.

COAL ASH. Environmental impact is always an issue in the land application of coal ash products. Of particular concern is the possibility that trace metals released from fly ash may be leached into groundwater. High application rates (40 or 80 $\mathrm{Mg} \cdot \mathrm{ha}^{-1}$ ) of the coal fly ash increased total concentrations of trace metals in amended surface soil ( $\mathrm{Li}$ and Chen, 2006). These metals may have the potential to leach through sandy or rocky soils into groundwater. The maximum concentrations of some metals in leachates were higher than the maximum contamination level specified for drinking water. However, the high concentrations of most metals in leachates are not only due to the application of coal fly ash because soils in the tested area have relatively high $\mathrm{Fe}, \mathrm{Cu}, \mathrm{Zn}, \mathrm{Cd}$, and other trace metals. Environmentally sound use of coal fly ash as a soil amendment may require setting maximum limits for trace metals in coal ash.

WTRs. Florida regulators are primarily concerned about trace metals, notably As and $\mathrm{Al}$, for land use of WTRs. Jain et al. (2005) reported that Al-WTRs produced in Florida contain total As concentrations $\left(8.5-16.9 \mathrm{mg} \cdot \mathrm{kg}^{-1}\right)$ that greatly exceed the industrial limit of soil cleanup target level (SCTL) for As. However, recent studies have shown that As contained in Al-WTRs is essentially nonlabile, and that Al-WTRs could indeed be used as a sorbent for As in soils (Makris et al., 2006; Sarkar et al., 2006). WTRs are also reported to potentially induce plant $\mathrm{P}$ deficiencies (Basta et al., 2000). Plant P uptake reductions and germination problems were observed when AlWTRs was applied (up to $40 \mathrm{Mg} \cdot \mathrm{ha}^{-1}$ ) (Rengasamy et al., 1980). Fescue grass yields were decreased in WTRsamended soil columns (up to 80 $\mathrm{Mg} \cdot \mathrm{ha}^{-1}$ ) in lieu of decreasing plantavailable $\mathrm{P}$ concentrations (Lucas et al., 1994). In addition to agronomic limitations involving $\mathrm{P}$ (overapplied WTRs induced plant P deficiencies); there are concerns about potential $\mathrm{Al}$ phytotoxicities. Florida studies have shown that when appropriate quantities of WTRs (based on the chemical characteristics of WTRs) are land applied, P deficiency and $\mathrm{Al}$ toxicity symptoms are not observed in plants (Oladeji, 2006). The availability/accessibility of sufficient quantities of WTRs and costs of transportation and application can be major limitations to the commercial use of WTRs. Field application rates of WTRs are usually large (12.5-25 tons/acre), and can outstrip local WTRs supplies when hundreds of hectares require treatment (Makris and O'Connor, 2007). Costs of transportation and application (labor and special equipment) for such large quantities of materials will probably prohibit widespread land application of WTRs, but opportunities for focused use remain.

Phosphogypsum. The major environmental concern for land application of phosphogypsum is radioactivity due to Ra in marine-deposited $P$ rock (Miller et al., 2000). The USEPA has determined that phosphogypsum can be used in unlimited 
quantities in agriculture as long as its ${ }^{226} \mathrm{Ra}$ content is $\leq 370 \mathrm{~Bq} \cdot \mathrm{kg}^{-1}$. The limit generally permits the use of phosphogypsum from northern Florida, but does not allow the use of central Florida phosphogypsum, which generally contains $\approx 925 \mathrm{~Bq} \cdot \mathrm{kg}^{-1}$ (Alcolordo et al., 1998).

\section{Current research}

Composts. Florida is a leader in research on compost utilization. The biomass program at the University of Florida, Institute of Food and Agricultural Sciences was established in 1980, and many compost research projects have been conducted since. Hyatt (1995) cited 56 compost research projects in 1993, 19 of which were conducted in Florida. Florida scientists continue to be active in compost research. Based on publications from the last 5 years, current research areas in Florida are: using compost for container media (Chen et al., 2002, 2003; Fitzpatrick, 2001; Li et al., 2009; Moore, 2005; Wilson et al., 2006), determining the impact of compost on water quality (Jaber et al., 2006), using compost for roadsite restoration (Harrell and Miller, 2005), developing testing methods for compost stability ( $\mathrm{Wu}$ and $\mathrm{Ma}$, 2002), and suppressing nematodes (Wang et al., 2007).

CoAl AsH. Li et al. (2002) conducted a 3-year study of fly ash as soil amendments to improve soil fertility in southern Florida sponsored by the Department of Energy. Fly ash additions improved soil fertility and crop yield and had insignificant impacts on accumulation of trace metals in soil, plant, fruit, and on groundwater quality. Greenhouse studies showed that fly ash amended at $18 \mathrm{~kg} \cdot \mathrm{m}^{-3}$ of potting media neutralized potting media $\mathrm{pH}$ and provided nutrients for ornamental plant growth (Chen and Li, 2006a, 2006b). Monitoring heavy metal leaching from the fly ash amended potting media during a 6-month plant production period indicated that As, Se, Mo, Cr, Pb, and mercury $(\mathrm{Hg})$ were not detectable in the leachates, and the amounts of $\mathrm{Cu}$, $\mathrm{Mn}, \mathrm{Ni}$, and $\mathrm{Zn}$ in weekly collected leachates were considerably lower $(\mathrm{Li}$ et al., 2008). The results suggest that fly ash could be beneficially used as a component of potting media for ornamental plant production with little concern for trace element leaching.
Wood ASH. There are no reports available for research related to land use of wood ash in Florida since 2000.

WTRs. Jain et al. (2005) characterized alum-, ferric-, and limebased WTR samples collected from 34 water treatment facilities in Florida. The research results were used to justify FDEP guidelines that severely limit land application of $\mathrm{Fe}$ - and $\mathrm{Al}$ WTRs in Florida despite abundant data that Jain et al. (2005) concerns were not well founded. O'Connor and his collaborators conducted many experiments on land application of WTRs and published several refereed publications in the last 5 years on the beneficial and safe use of WTRs in Florida (Agyin-Birikorang et al., 2007; Agyin-Birikorang and O'Connor, 2007; Makris et al., 2004a, 2004b, 2005a, 2005b, 2005c; Makris and O'Connor, 2007; O'Connor et al., 2002, 2005; Oladeji et al., 2006, 2007; Silveira et al., 2006; Van Alstyne et al., 2006).

Phosphogypsum. Rechcigl and his collaborators conducted many experiments and published many papers on land use of phosphogypsum in Florida. However, their last research project on phosphogypsum was "Predicting the long term impact of high rates of phosphogypsum applications on radioactivity in soil, groundwater, and bahiagrass forage, and on radon emissions" and was reported in 1998 (Florida Institute of Phosphorus Research, 2007). The study found that phosphogypsum at 10 and $20 \mathrm{Mg} \cdot \mathrm{ha}^{-1}$ resulted in statistically measurable increases in soil ${ }^{226} \mathrm{Ra}$ at the top $5 \mathrm{~cm}$ during the 2 -year study period. There is no report available for research related to land use of phosphogypsum in Florida since then.

\section{Research needs}

- Improve estimates of (and field validate) $\mathrm{N}$ mineralization rates from organic wastes in a variety of climatic conditions in Florida. Estimation is critical for determining appropriate application rates.

- Validate the Florida P index and BMPs associated with land application of wastes.

- Standardize analytical methods of solid wastes. Develop a quick method for determining maturity of compost.

- Develop passive (low-maintenance) composting systems for producers.
- Develop and demonstrate simple composting devices for household use.

- Continue to be at the forefront of regulation and $\mathrm{BMP}$ development for waste utilization and educational efforts to better inform decision makers and the general public about sustainable and environmentally friendly waste utilization.

- Evaluate economically viable alternatives for transporting and applying waste materials.

- Research market development for compost and other wastes.

- Develop a database to document all research reports conducted in Florida.

\section{Outreach needs}

- Develop extension programs to educate regulators, policymakers, and local officers.

- Educate the public to encourage recycling and reuse of wastes.

- Involve land owners and growers in research and demonstration projects.

- Develop a better website for recycling and reusing wastes.

- Develop simple and easy-toread educational materials.

- Back up extension programs with solid research.

- Encourage researchers to include education, social and political factor components in their research program.

- Encourage researchers to develop research and extension intergraded projects.

\section{Literature cited}

Agyin-Birikorang, S. and G.A. O'Connor. 2007. Lability of drinking-water treatment residuals (WTRs) immobilized phosphorus: Aging and $\mathrm{pH}$ effects. J. Environ. Qual. 36:1076-1085.

Agyin-Birikorang, S., G.A. O'Connor, L.W. Jacobs, K.C. Makris, and S.R. Brinton. 2007. Long-term phosphorus immobilization by a drinking water treatment residual. J. Environ. Qual. 36:316-323.

Alcolordo, I.S., J.E. Reschcigl, R.C. Littell, A.K. Alva, and C.E. Roessler. 1998. Agroenvironmental impact of high rates of phosphogypsum applied to bahiagrass pasture on a Florida Spodosol soil, p. 423-430. In: S. Brown, J.S. Angle, and L. Jacobs (eds.). Beneficial co-utilization of agricultural municipal and industrial by-products. Kluwer Academic, New York. 
American Coal Ash Association. 2001. CCP production and use survey: 2000 . American Coal Ash Assn., Syracuse, NY.

American Society of Civil Engineers. 1996. Technology transfer handbook: Management of water treatment plant residuals. ASCE and American Water Works Assn., New York.

Barker, A.V., T.A. O’Brien, and M.L. Stratton. 2000. Description of food processing by products, p. 63-106. In: W.A. Dick and J.M. Bartels (eds.). Land application of agricultural, industrial, and municipal by-products. SSSA Book Series No. 6. Soil Sci. Soc. Amer., Madison, WI.

Basta, N.T., R.J. Zupanic, and E.A. Dayton. 2000. Evaluating soil tests to predict bermudagrass growth in drinking water treatment residuals with phosphorus fertilizer. J. Environ. Qual. 29: 2007-2012.

Brown, R.B., E.L. Stone, and V.W. Carlisle. 1990. Soils, p. 35-69. In: R.L. Myers and J. Ewel (eds.). Ecosystem of Florida. University Press of Florida, Gainesville, FL.

Bryan, H.H., B. Schaffer, R.E. Sanford, and M. Codallo. 1995. Growth and yield of tomato in calcareous soil amended with municipal solid waste compost. Proc. Florida State Hort. Soc. 108:251-253.

Bryan, H.H., J. Ramo, M. Codallo, and J.W. Scott. 1997. Effects of soil fumigation, compost, and non-fumigation on the yield, fruit quality, disease incidence, and other variables of tomato cultivars. Proc. Florida State Hort. Soc. 110:269-272.

Chellemi, D.O., D.J. Mitchell, and A.W. Barkdol. 1992. Effect of composted organic amendments on the incidence of bacterial wilt to tomato. Proc. Florida State Hort. Soc. 105:364-366.

Chen, J. and Y.C. Li. 2006a. Amendment of fly ash to container substrates for ornamental plant production, p. 177183. In: K.S. Sajwan, I. Twardowska, T. Punshon and A.K. Alva (eds.). Coal combustion byproducts and environmental issues. Springer-Verlag, New York.

Chen, J. and Y.C. Li. 2006b. Coal fly ash as an amendment to container substrate for Spathiphyllum production. Bioresour. Technol. 97:1920-1926.

Chen, J., D.B. McConnell, C.A. Robinson, R.D. Caldwell, and Y. Huang. 2002. Production and interior performances of tropical ornamental foliage plants grown in container substrates amended with composts. Compost Sci. Util. 10:217-225.

Chen, J., D.B. McConnell, C.A. Robinson, R.D. Caldwell, and Y. Huang. 2003. Rooting foliage plant cuttings in compost- formulated substrates. HortTechnology 13:110-114.

Chirenje, T. and L.Q. Ma. 2002. Impacts of high-volume papermill ash amendment on soil properties and nutrient status. Commun. Soil Sci. Plant Anal. 33:1-17.

Chwirka, J.D., R. Narasimhan, N. Scheuer, and G. Rousseau. 2001. The impact of residuals on the selection of an As treatment process. Water Environ. Federation/ Amer. Water Works Assn./California Water Environ. Assn. Joint Residuals and Biosolids Management Conf. Proc. Biosolids 2001: Building Public Support. CDROM(Abstr.).

Clark, G.A., C.D. Stanley, and D.N Maynard. 1995. Municipal solid waste compost in irrigated vegetable production. Proc. Soil Crop Sci. Soc. Fla. 54: 49-53.

Csizinszky, A.A. and C.D. Stanley. 1998. Response of tomatoes to microirrigation rates, compost placement and rates and $\mathrm{N}$ and K sources. Proc. Florida State Hort. Soc. 111:73-77.

Dayton, E.A., N.T. Basta, C.A. Jakober, and J.A. Hattey. 2003. Using treatment residuals to reduce phosphorus in agricultural runoff. J. Amer. Water Works Assn. 95:151-157.

Elliott, H.A. and B.A. Dempsey. 1991. Agronomic effects of land application of water treatment sludges. J. Amer. Water Works Assn. 83:126-131.

Elliott, H.A., B.A. Dempsey, D.W Hamilton, and J.R. DeWolfe. 1990. Land application of water treatment sludges: Impact and management. Amer. Water Works Assn. Res. Foundation. p. 100 (Abstr.)

Elliott, H.A., G.A. O'Connor, P. Lu, and S. Brinton. 2002. Influence of water treatment residuals on phosphorus solubility and leaching. J. Environ. Qual. 31:1362-1369.

Epstein, E. 1997. The science of composting. CRC Press, Boca Raton, FL.

Fitzpatrick, G.E. 2001. Compost utilization in ornamental and nursery crop production systems, p. 135-150. In: P.J. Stoffella and B.A. Kahn (eds.). Compost utilization in horticultural cropping systems. Lewis Publ., Boca Raton, FL.

Florida Department of Environmental Protection. 2000. Criteria for the production and use of compost made from solid waste. 23 Apr. 2009. <http:// www.dep.state.fl.us/waste/quick_topics/ rules/documents/62-709.pdf>.

Florida Department of Environmental Protection. 2002. Management of components of yard trash: Dirt, ash and mulch. Memo No. SWM-05.6. Solid Waste Section, Florida Dept. Environ. Protection, Tallahassee, FL.

Florida Department of Environmental Protection. 2006. Guidance for land application of drinking water treatment sludge. Solid Waste Section, Florida Dept. Environ. Protection, Tallahassee, FL.

Florida Department of Environmental Protection. 2007a. Recycling: 2006 Solid waste annual report. 26 May 2009. <http:// www.dep.state.fl.us/waste/categories/ recycling/SWreportdata/06_data.htm>

Florida Department of Environmental Protection. 2007b. Water assurance compliance system (WACS): Solid waste solid waste facility inventory report. $21 \mathrm{Apr}$. 2009. <http://appprod.dep.state.fl.us/ WWW_WACS/Reports/SW_Facility_ Inventory_Pl.asp>.

Florida Department of Environmental Protection. 2009. Waste management rules. 27 May 2009. <http://www.dep.state.fl. us/waste/quick_topics/rules/>.

Florida Institute of Phosphorus Research. Phosphogypsum use. 2007. 12 Nov. 2008. <http://www.fipr.state.fl.us/FIPR report $2003 /$ research-highlights-pg-use. htm>.

Gainer, K. 1996. Commercial use of coal combustion byproducts: Technologies and markets. Business Communications Co., Norwalk, CT.

Gallimore, L.E., N.T. Basta, D.E. Storm, M.E. Payton, R.H. Huhnke, and M.D. Smolen. 1999. Use of water treatment residuals to reduce nutrients in surface runoff from agricultural land. J. Environ. Qual. 28:1474-1478.

Goodrich, R.M. and R.J. Braddock. 2006. Major by-products of the Florida citrus processing industry. 20 Oct. 2008. $<$ http://edis.ifas.ufl.edu/pdffiles/FS/ FS10700.pdf $>$.

Harrell, M.S. and G.L. Miller. 2005. Composted yard waste affects soil displacement and roadside vegetation. HortScience 40:2157-2163.

Haustein, G.K., T.C. Daniel, D.M. Miller, P.A. Moore, Jr., and R.W. McNew. 2000. Aluminum-containing residuals influence high phosphorus soils and runoff water quality. J. Environ. Qual. 29:1954-1959.

He, Z.L., A.K. Alva, P. Yan, Y.C. Li, D.V. Calvert, P.J. Stoffella, and D.J. Banks. 2000. Nitrogen mineralization and transformation from composts and biosolids during field incubation in a sandy soil. Soil Sci. 165:161-169.

He, Z.L., A.K. Alva, Y.C. Li, D.V. Calvert, and D.J. Banks. 1999. Sorption-desorption 
and solution concentration of phosphorus in a fertilized sandy soil. J. Environ. Qual. 28:1804-1810.

Hughes, J.C., L.W. Titshall, M. Buyeye, M.A. Johnston, M. Moodley, and S. Pecku. 2005. Effects of land application of water treatment residue. Rpt. No. 1148/1/05. Water Research Commission, Pretoria, South Africa.

Hurt, G.W., R.S. Mylavarapu, and S.P. Boetger. 2006. UF/IFAS nutrient management series: Computational tools for field implementation of the Florida phosphorus index: Okeechobee Watershed Area. 15 June 2009. <http://edis.ifas.ufl. $\mathrm{edu} / \mathrm{SS} 462>$.

Hyatt, G.W. 1995. Economic, scientific, and infrastructure basis for using municipal composts in agriculture, p. 19-72. In: D.L. Karlen, R.J. Wright, and W.D. Kemper (eds.). Agricultural utilization of urban and industrial by-products. ASA Spec. Publ. No. 58. American Society of Agronomy, Madison, WI.

Jaber, F.H., S. Shukla, E.A. Hanlon, P.J. Stoffella, T.A. Obreza, and H.H. Bryan. 2006. Groundwater phosphorus and trace element concentrations from organically amended sandy and calcareous soils of Florida. Compost Sci. Util. 14:6-15.

Jain, P., J. Yong-Chul, T. Thabet, M. Witwer, and T. Townsend. 2005. Recycling of water treatment plant sludge via land application: Assessment of risk. J. Res. Sci. Technol. 2:13-23.

Jamieson, J.C., J. White, and M. OzoresHampton. 2003. Progressive state regulations in food waste composting. 22 Oct. 2008. <http://rmg.us/Progressive_ Regulations_in_Food_Waste_Composting. doc $>$.

Kessler Consulting, Inc.. 2006. FORCE Florida composting regulatory report. 11 Nov. 2008. <http://www.floridaforce. org/images/docs/Organicsregulatory FinalReport.pdf $>$.

Li, Q., J. Chen, and Y. Li. 2008. Heavy metal leaching from coal fly ash-amended container substrates during Syngonium production. J. Environ. Sci. Health B 43: 179-186.

Li, Q., J. Chen, R.D. Caldwell, and M. Deng. 2009. Cowpeat as a substitute for peat in container substrates for foliage plant propagation. HortTechnology 19: 340-345.

Li, Y.C. and J. Chen. 2006. Leachability of heavy metals from sandy or rocky soils amended with coal fly ash, p. 105-113. In: K.S. Sajwan, I. Twardowska, T. Punshon and A.K. Alva (eds.). Coal combustion byproducts and environmental issues. Springer-Verlag, New York.
Li, Y.C., M. Zhang, and P.J. Stoffella. 2002. Utilization of fly ash and urban yard waste as soil amendments to improve soil fertility. Final Rpt. No. TREC-LI02-06. Tropical Research and Education Center, University of Florida, Homestead.

Li, Y.C., P. Stoffella, and H.H. Bryan. 2000. Management of organic amendments in vegetable system production in Florida. Proc. Soil Crop Sci. Soc. Fla. 59:17-21.

Li, Y.C., P.J. Stoffella, A.K. Alva, D.V. Calvert, and D.A. Graetz. 1997. Leaching of nitrate, ammonium, and phosphate from compost amended soil columns. Compost Sci. Util. 5:63-67.

Litvany, M. and M. Ozores-Hampton. 2002. Compost use in commercial citrus in Florida. Hort Technology 12:332-335.

Livesey, N.T. and P.M. Huang. 1981. Adsorption of arsenate by soils and its relationship to selected chemical properties and anions. Soil Sci. 131:88-94.

Lucas, J.B., T.A. Dillaha, R.B. Reneau, J.T. Novak, and W.R. Knocke. 1994. Alum sludge land application and its effect on plant growth. J. Amer. Water Works Assn. 86:75-83.

Makris, K.C. and G.A. O'Connor. 2007. Beneficial utilization of drinking-water treatment residuals as contaminant-mitigating agents, p. 607-636. In: D. Sarkar (ed.). Developments in environmental science, Volume 5: Concepts and applications in environmental geochemistry. Elsevier Science, Amsterdam, The Netherlands.

Makris, K.C., D. Sarkar, and R. Datta. 2006. Evaluating a drinking-water waste by-product as a novel sorbent for As. Chemosphere 64:730-741.

Makris, K.C., H. El-Shall, W.G. Harris, G.A. O'Connor, and T.A. Obreza. 2004a. Intraparticle P diffusion in a drinking water residual at room temperature. J. Colloid Interface Sci. 277:417-423.

Makris, K.C., W.G. Harris, G.A. O’Connor, and T.A. Obreza. 2004b. Phosphorus immobilization in micropore of drinkingwater treatment residuals: Implications for long-term stability. Environ. Sci. Technol. 38:6590-6596.

Makris, K.C., W.G. Harris, G.A. O'Connor, T.A. Obreza, and H.A. Elliott. 2005a. Physiochemical properties related to long-term phosphorus retention by drinking water treatment residuals. Environ. Sci. Technol. 39:4280-4289.

Makris, K.C., W.G. Harris, G.A. O'Connor, and T.A. Obreza. 2005b. Long-term phosphorus effects on evolving physicochemical properties of iron and $\mathrm{Al}$ hydroxides. J. Colloid Interface Sci. 287: 552-560.

Makris, K.C., G.A. O’Connor, W.G. Harris, and T.A. Obreza. 2005c. Relative efficacy of a drinking water treatment residual and alum in reducing phosphorus release from poultry litter. Commun. Soil Sci. Plant Anal. 36:2657-2675.

Mannion, C.M., B. Schaffer, M. OzoresHampton, H.H. Bryan, and R. McSorley. 1994. Nematode population dynamics in municipal solid waste amended soil during tomato and squash cultivation. Nematropica 24:17-24.

Maurer, M. and M. Boller. 1999. Modeling of $\mathrm{P}$ precipitation in wastewater treatment plants with enhanced biological $\mathrm{P}$ removal. Water Sci. Technol. 39:147163.

Miller, D.M., W.P. Miller, S. Dudka, and M.E. Sumner. 2000. Characterization of industrial by-products, p. 107-126. In: Land application agricultural, industrial, and municipal by-products. SSSA Book Series No. 6. Soil Sci. Soc. Amer, Madison, WI.

Moore, K.K. 2005. Uses of compost in potting mixes. HortTechnolnology 15: 58-60.

Moss, L.H., E. Epstein, and T. Logan. 2002. Evaluating risks and benefits of soil amendments used in agriculture. Rpt. 99PUM-1. Water Environment Research Foundation, Alexandria, VA.

Nair, V.D. and D.A. Graetz. 2002. Phosphorus saturation in Spodosols impacted by manure. J. Environ. Qual. 31:12791285.

Novak, J.M. and D.W. Watts. 2004. Increasing the phosphorus sorption capacity of southeastern coastal plain soils using water treatment residuals. Soil Sci. 169: 206-214.

Obreza, T.A. and R.K. Reeder. 1994. Municipal solid waste compost use in a tomato/ watermelon successional cropping. Proc. Soil Crop Sci. Soc. Fla. 53:1319.

O'Connor, G.A., H.A. Elliott, and P. Lu. 2002. Characterizing water treatment residuals phosphorus retention. Proc. Soil Crop Sci. Soc. Fla. 61:67-73.

O'Connor, G.A., S. Brinton, and M.L. Silveira. 2005. Evaluation and selection of soil amendments for field testing to reduce P losses. Proc. Soil Crop Sci. Soc. Fla. 64:22-34.

Oladeji, O.O. 2006. Management of phosphorus sources and water treatment residuals (WTR) for environmental and agronomic benefits. Univ. Florida. Gainesville, Ph.D. diss. 
Oladeji, O.O., G.A. O’Connor, J.B. Sartain, and V.D. Nair. 2007. Controlled application rate of water treatment residual for agronomic and environmental benefits. J. Environ. Qual. 36:1715-1724.

Oladeji, O.O., J.B. Sartain, and G.A. O'Connor. 2006. Agronomic impact of water treatment residual co-applied with phosphorus sources to Florida sands. Proc. Soil Crop Sci. Soc. Fla. 65:38-48.

Oladeji, O.O., S. Agyin-Birikorang, G.A. O'Connor, T.A. Obreza, and J.C. Capece. 2009. Reducing off-site phosphorus loss from a Florida Spodosol amended with different phosphorus sources. J. Environ. Qual. (in press)

Olexa, M.T., A. Leviten, and K. Samek. 2003. Florida solid and hazardous waste regulation handbook: Composting. 11 Dec. 2008. <http://edis.ifas.ufl.edu/ pdffiles/FE/FE46200.pdf $>$.

Ozores-Hampton, H.B. and R. McMillan. 1994. Suppressing disease in field crops. Biocycle 35:60-61.

Ozores-Hampton, M. and T. Obreza. 2007. Compost facilities in Florida. 22 Oct. 2008. <http://www.imok.ufl.edu/ compost/utilization/table_l.htm>.

Ozores-Hampton, M., E. Hanlon, H. Bryan, and B. Schaffer. 1997. Cadmium, copper, lead, nickel and zinc concentrations in tomato and squash grown in MSW compost-amended calcareous soil. Compost Sci. Util. 5:40-45.

Ozores-Hampton, M., T.A. Obreza, and G. Hochmuth. 1998. Using composted wastes on Florida vegetable crops. HortTechnology 8:130-137.

Prakash, P. and A.K. Sengupta. 2003. Selective coagulant recovery from water treatment plant residuals using Donnan membrane process. Environ. Sci. Technol. 37:4468-4474.

Rechcigl, J.E. and P. Mislevy. 1997. Stargrass response to lime and phosphogypsum. J. Prod. Agr. 10:101-105.

Rengasamy, P., J.M. Oades, and T.W. Hancock. 1980. Improvement of soil structure and plant growth by addition of alum sludge. Commun. Soil Sci. Plant Anal. 11:533-545.

Risse, M. and G. Harris. 2007. Best management practices for wood ash used as an agricultural soil amendment, soil acidity and liming for the Internet in-service training. 22 Oct. 2008. <http://hubcap.clemson. edu/ blpprt/bestwoodash.html>.

Ritzinger, C.H., R. McSorley, and R.N. Gallaher. 1997. Effect of organic amendment placement and inoculum density of Meloidogyne arenaria on okra seedlings. Proc. Soil Crop Sci. Soc. Fla. 56:28-31.

Roe, N.E., P.J. Stoffella, and D.A. Graetz. 1997. Composts from various municipal feedstocks affect vegetable crops. II. Growth, yields, and fruit quality. J. Amer. Soc. Hort. Sci. 122:433-437.

Sarkar, D., K.C. Makris, V. Vandanapu, and R. Datta. 2006. Arsenic immobilization in soils amended with drinking-water treatment residuals. Environ. Pollut. 146:414-419.

Shieh, C. 1998. Wood ash in Florida: Production and characteristics-phase I. 22 Oct. 2008. <http://www.hinkleycenter.com/ publications/wood_ash_phaseI_98-6.pdf>.

Shiralipour, A. 1998. Developing a market for compost products, p. 15-17. In: A report of compost use in Florida. $12 \mathrm{Nov}$. 2008. <http://www.dep.state.fl.us/ waste/quick_topics/publications/documents/compost.pdf>.

Silveira, M.L., M.K. Miyittah, and G.A. O'Connor. 2006. Phosphorus release from a manure-impacted Spodosol: Effects of a water treatment residual. J. Environ. Qual. 35:529-541.

Slivka, D.C., T.A. McClure, A. Buhr, and R.A. Albrecht. 1992. Compost: United States supply and demand potential. Biomass Bioenergy 3:281-299.

Stoffella, P.J. and D.A. Graetz. 2000. Utilization of sugarcane compost as a soil amendment in a tomato production system. Compost Sci. Util. 8:210-214.

Stoffella, P.J. and Y.C. Li. 2001. Utilization of organic amendments in vegetable cropping systems. Proc. Interamer. Soc. Trop. Hort. 47:104-105.

Stoffella, P.J., Y.C. Li, D.V. Calvert, and D.A. Graetz. 1996. Soilless growing media amended with sugarcane filter cake compost for citrus rootstock production. Compost Sci. Util. 4:21-25.

Stoffella, P.J., Y. Li, N.E. Roe, M. Ozores-Hampton, and D.A. Graetz. 1997. Utilization of organic waste composts in vegetable crop production sys- tem, p. 253-269. In: R.A. Morris (ed.). Managing soil fertility for intensive vegetable production systems in Asia. Asian Veg. Res. Dev. Center, Tainan, Taiwan.

Townsend, T.G., Y.C. Jang, P. Jain, and T. Tolayma. 2001. Characterization of drinking water sludges for beneficial reuse and disposal. 22 Oct. 2008. <http:// www.dep.state.fl.us/waste/quick_topics/ publications/shw/solid_waste/Drinking WaterSludgeCharacterization.pdf>.

Townsend, W.N. and D.R. Hodgson. 1973. Edaphological problems associated with deposits of pulverized fuel ash, p. 4556. In: R.J. Huntick and G. Davis (eds.). Ecology and reclamation of devastated land. Vol. 1. Gordon and Breach, New York.

Van Alstyne, R., L.R. McDowell, P.A. Davis, N.S. Wilkinson, L.K. Warren, and G.A. O'Connor. 2006. Effects of dietary $\mathrm{Al}$ from an $\mathrm{Al}$ water treatment residual on bone mineral content of feeder lambs. Prof. Anim. Sci. 22:153-157.

Wang, Q., Y. Li, W. Klassen, and Z. Handoo. 2007. Influence of cover crops and soil organic amendments on okra (Abelmoschul esculentus L.) production and soil nematodes. Renewable Agr. Food Systems 22:41-53.

Westendorf, M.L. and R.O. Myer. 2004. Feeding food wastes to swine. 30 Oct. 2008. <http://edis.ifas.ufl.edu/ANI43>.

Wilson, S.B., L.K. Mecca, H.E. Danielson, D.A. Graetz, and P.J. Stoffella. 2006. Container and field evaluation of three native shrubs grown in compost-based media. Compost Sci. Util. 14:178-183.

Wu, L. and L.Q. Ma. 2002. Relationship between compost stability and extractable organic carbon. J. Environ. Qual. 31:13231328.

Zinati, G.M., Y.C. Li, and H.H. Bryan. 2001. Utilization of compost increases organic carbon and its humin, humic and fulvic acid fractions in calcareous soil. Compost Sci. Util. 9:156-162.

Zinati, G.M., Y.C. Li, H.H. Bryan, R. Mylavarapu, and M. Codallo. 2004. Distribution and fractionation of phosphorus, cadmium, nickel, and lead in calcareous soils amended with composts. J. Environ. Sci. Health B 39:209-223. 